\title{
Reflections on the Role of State Courts in the Vindication of State Constitutional Rights: A Plea for State Appellate Courts to Consider Unraised Issues of State Constitutional Law in Criminal Cases
}

\author{
Michael A. Berch*
}

This Essay examines the persistent failures of counsel in criminal cases to raise state constitutional claims ${ }^{1}$ and the reluctance of state judges to excuse waivers of state constitutional rights. ${ }^{2}$ The Essay sets

\footnotetext{
* Michael A. Berch, Alan Matheson Distinguished Professor of Law, Sandra Day O’Connor College of Law, Arizona State University. Let me express my appreciation to Professor Stephen McAllister and the members of the Kansas Law Review for inviting me and my wife, Chief Justice Rebecca White Berch of the Arizona Supreme Court, to participate at the Kansas Law Review Symposium, State Constitutional Law Steps Out of the Shadows. This Essay grew out of that presentation.

I gratefully acknowledge the assistance of Elizabeth DiFelice, Assistant Director of the Ross Blakley library of the Sandra Day O'Connor College of Law. I also extend appreciation to the editors and staff of the Kansas Law Review for their dedication to the Symposium and to this Essay.

As always, I am grateful to my wife, Chief Justice Rebecca White Berch of the Arizona Supreme Court, for her comments and suggestions regarding this manuscript. None of the views expressed in the piece should be attributed to her or to any other member of the court.

1. As Robert Williams stated, "Despite the development of the New Judicial Federalism nearly two generations ago, lawyers still fail to properly argue the state constitutional grounds where available.” Robert F. Williams, Introduction: The Third Stage of the New Judicial Federalism, 59 N.Y.U. ANN. SuRV. AM. L. 211, 220 (2003); see also Vincent Martin Bonventre, Changing Roles: The Supreme Court and the State High Courts in Safeguarding Rights, 70 ALB. L. REV. 841, 853 (2007); William J. Brennan, Jr., State Constitutions and the Protection of Individual Rights, 90 HARV. L. ReV. 489, 502 (1977); Susan Gellman, Sticks and Stones Can Put You in Jail, but Can Words Increase Your Sentence? Constitutional and Policy Dilemmas of Ethnic Intimidation Laws, 39 UCLA L. Rev. 333, 343-44 (1991); Kimberly S. Keller, Privacy Lost: Comparing the Attenuation of Texas's Article I, Section 9 and the Fourth Amendment, 34 ST. MARY’s L.J. 429, 451-52 (2003).

2. Many state courts, with little or no discussion, strictly apply the waiver rule to the failure to raise state constitutional claims in the lower courts. See, e.g., State v. Martinez, 236 P.3d 481, 500 (Kan. 2010) (finding that question of whether minimum sentence of twenty-five years for attempted rape of a fourteen-year-old violates state constitution's cruel and unusual punishment provision was not properly before the appellate tribunal because it was not raised in trial court); State v. Martin, 773 N.W.2d 89, 100 n.6 (Minn. 2009) (rejecting argument that the Minnesota Constitution requires higher levels of scrutiny for Batson challenges than the U.S. Constitution because it was not raised at the trial level); State v. Sletten, 664 N.W.2d 870, 875 (Minn. App. 2003) (declining to reach "automatic standing" state constitutional issue not raised in trial court); State v. Munoz, 187 P.3d
} 
forth and develops the theme that courts should abandon the strict waiver rule of state constitutional rights in order to avoid gross injustices to defendants in criminal cases occasioned by counsel's forfeiture of significant constitutional rights. The liberal waiver approach advanced in this Essay would also afford the state judiciary the opportunity to develop state constitutional law that may be more protective of the rights and liberties of persons subject to their jurisdiction. The strict waiver

696, 703-04 (N.M. Ct. App. 2008) (precluding defendant from raising a state constitutional issue for first time on appeal); State v. Vaughn, 114 P.3d 354, 357-58 (N.M. Ct. App. 2005) (finding that a state double jeopardy claim not raised in trial court was not preserved); Richter v. N.D. Dep't of Transp., 786 N.W.2d 716, 724 (N.D. 2010) (holding that suppression of evidence under North Dakota law would not be considered on appeal when not raised in the court below or adequately supported in the appellate brief); Commonwealth v. Santiago, 980 A.2d 659, 666 n.6 (Pa. Super. Ct. 2009) (finding that protection of un-Mirandized statements under state constitution is not considered when the only Fifth Amendment grounds were originally briefed); Black v. State, 26 S.W.3d 895, 896 n.4 (Tex. Crim. App. 2000) (refusing to excuse waiver of state equal protection clause). Still other courts recognize discretion to relieve a party under limited circumstances such as a finding of manifest injustice or the impact of the waiver on the fairness of the proceedings. See, e.g., Kramer v. Gates, 481 F.3d 788, 791 (D.C. Cir. 2007) (noting that court has authority to raise issue when "'errors are obvious, or if they otherwise seriously affect the fairness, integrity, or public reputation of judicial proceedings'” (quoting United States v. TDC Mgmt. Corp., 288 F.3d 421, 425 (D.C. Cir. 2002))); Pichardo v. Ashcroft, 374 F.3d 46, 54 (2d Cir. 2004) (“[W]aiver 'rule is one of prudence ... and [is] not jurisdictional.'” (quoting Official Comm. of Unsecured Creditors of Color Tile, Inc. v. Coopers \& Lybrand, LLP, 322 F.3d 147, 159 (2d Cir. 2003))); United States v. Portillo-Mendoza, 273 F.3d 1224, 1227 (9th Cir. 2001) (““'II]n exceptional circumstances, especially in criminal cases, appellate courts ... may ... notice errors to which no exception has been taken ....”' (quoting United States v. Atkinson, 297 U.S. 157, 160 (1936))); People v. Lopez, No. B 175588, 2005 WL 1119790 , at *3 (Cal. Ct. App. May 12, 2005) (considering a California cruel or unusual punishment claim even though the defendant did not raise the issue at trial court); State v. Marroquin, 168 P.3d 1246, 1249 n.4 (Or. Ct. App. 2007) (addressing an improperly raised claim under the state constitution rather than addressing the properly raised Sixth Amendment claim and stating that "an Oregon court should not readily let parties, simply by their choice of issues, force the court into a position to decide that the state's government has fallen below a nationwide constitutional standard, when in fact the state's law, when properly invoked, meets or exceeds that standard" (quoting State v. Kennedy, 666 P.2d 1316, 1320 (1983))). Several courts opine that resolution of the issue must be beyond doubt. Cf. Singleton v. Wulff, 428 U.S. 106, 120-21 (1976) (exercising discretion to excuse the waiver when the proper resolution of the issue is beyond doubt). This Essay advances a more liberal approach. If the error relates to the failure to raise a state constitutional guarantee in a felony or other serious criminal proceeding and the failure to raise the issue casts doubt on the legitimacy of the conviction or the severity of the sentence, the state courts should engage in issue creation and consider the unraised issue, unless doing so would pose major problems in the administration of justice. Moreover, there may be circumstances in which the state courts should recognize a mandatory duty to address the issue that has not been raised in the lower courts-for example, where the state constitutional right has been recently decided by the highest court of the state, clearly benefits the criminal defendant, and would overturn the judgment of conviction or the imposition of the punishment. The parties should be given the opportunity to submit written briefs on the question of whether the waiver should be excused. If failure to raise is excused, the parties should also have the right to present briefs on the substantive issues and perhaps even the opportunity to present oral argument. The high court may also appoint amici to argue the substantive issues that it has undertaken to resolve. 
rule seriously impedes these two goals. After pointing out several problems with adopting a liberal waiver approach, the Essay concludes that on balance it is the preferable method of dealing with counsel's failures to raise state constitutional issues.

Of course, where federal constitutional guarantees are at issue, state courts may very well have an obligation under federal law to relieve the defendant from the waiver. ${ }^{3}$ The U.S. Supreme Court has recognized that waiver of federally protected trial rights must be made knowingly, intelligently, and voluntarily. ${ }^{4}$ These rights include the right to trial by jury, the right to counsel, the protection against double jeopardy, ${ }^{5}$ and the protection against cruel and unusual punishment, at least in death penalty cases. ${ }^{6}$ State courts are bound by these decisions. On the other hand, Fourth Amendment guarantees against unreasonable search and seizure are not directly related to the trial proceedings and, consequently, waivers based on these claims are not scrutinized with the same degree of rigor. ${ }^{7}$ It would also appear that state courts need not adopt the "knowing and voluntary" requirement in state criminal proceedings invoking state constitutional protection, although the serious implications of the rejection of that standard should be clearly understood. Yet state courts often refuse, without elaboration, to relieve the defendant from the oversights of counsel, thereby placing guarantees provided under state law in serious jeopardy. ${ }^{8}$ Judicial opinions seldom address why this is so.

The liberal approach developed in this Essay will be rejected by a number of scholars and judges as unworthy of serious consideration. After all, it casts into doubt core principles of the American adversary system, which are seldom, if ever, questioned in our country. ${ }^{9}$ But for

3. Some jurists may view the matter as not involving a waiver in the first place rather than as excusing one. These semantic distinctions, if they have any validity in other contexts, are of no importance to the development of my thesis.

4. See Dale E. Ho, Silent at Sentencing: Waiver Doctrine and a Capital Defendant's Right to Present Mitigating Evidence After Schiro v. Landrigan, 62 FLA. L. REV. 721, 733 (2010).

5. See id.

6. Regarding counsel's failure to uncover or present mitigating factors in death penalty cases, the Court on three occasions has issued opinions sustaining ineffectiveness of counsel claims. Rompilla v. Beard, 545 U.S. 374 (2005); Wiggins v. Smith, 539 U.S. 510 (2003); Williams v. Taylor, 529 U.S. 362 (2000). Only the defendant may knowingly and intelligently waive these rights. See Ho, supra note 4, at 732-35. However, a defendant's knowing waiver may not be sufficient in all cases. See infra note 90 and accompanying text.

7. See Ho, supra note 4, at 734-35; see also infra note 10.

8. See supra note 2.

9. See generally Sarah M. R. Cravens, Involved Appellate Judging, 88 MARQ. L. REV. 251, 
reasons developed later in this Essay, we should engage in this conversation and entertain these suggestions for liberalizing the waiver of state constitutional rights in state courts for serious criminal proceedings. Apart from comporting with time-honored tradition, sound reasons to justify application of the strict waiver doctrine appear lacking in the decisions. ${ }^{10}$

For at least three decades, a significant problem in the administration of criminal justice in the state courts has persisted: the loss of fundamental rights guaranteed by state constitutions through failure of counsel to raise the issue in the trial court, coupled with strict application by appellate judges of the waiver doctrine. ${ }^{11}$ Many questions should be addressed in connection with the proposal to excuse these waivers. When counsel fails to initially raise state constitutional protections based on the declaration of rights contained in the state constitution, what should appellate courts do? Should they take on a more active role in the dispensation of justice and raise the issues themselves? The received wisdom exclaims: No. If a party fails to raise an issue in the lower courts or during an appeal, that party has waived the issue. ${ }^{12}$

Other questions emerge as well. Why do we even entertain a waiver doctrine ${ }^{13}$ Are the reasons so compelling that they foreclose consideration of any unraised state constitutional rights in criminal

294 (2004) (arguing that appellate judges should have more discretion to find the "most correct resolution" of legal questions even when certain issues are not argued); Amanda Frost, The Limits of Advocacy, 59 DUKE L.J. 447, 452 (2009) (promoting judicial issue creation in certain cases).

10. Indeed any other standard does violence to the American tradition of giving defendants every opportunity to absolve themselves from the consequences of a conviction or sentence. As stated by the Court:

A strict standard of waiver has been applied to those rights guaranteed to a criminal defendant to insure that he will be accorded the greatest possible opportunity to utilize every facet of the constitutional model of a fair criminal trial. Any trial conducted in derogation of that model leaves open the possibility that the trial reached an unfair result precisely because all the protections specified in the Constitution were not provided. . . .

The protections of the Fourth Amendment are of a wholly different order, and have nothing whatever to do with promoting the fair ascertainment of truth at a criminal trial.

Schneckloth v. Bustamonte, 412 U.S. 218, 241 (1973); see also Ho, supra note 4, at 735. When the Court uses the term "strict standard of waiver" in this passage it is referring to the difficulty of waiving certain fundamental constitutional rights. In this Essay I use the term "liberal rule of waiver" to refer to the ease of excusing the loss of constitutional rights through waiver.

11. A variation of this theme is presented when counsel raises the state claim in the lower courts but thereafter fails to pursue it in the highest state court. See infra note 60 and accompanying text.

12. See supra note 2 .

13. See Charles Alan Wright \& Andrew D. Leipold, 1A Federal Practice AND PROCEDURE: CRIMINAL § 193 (4th ed. 2008 \& Supp. 2010) (covering waiver by failure to make motion). 
cases? Should strict application of the waiver doctrine be examined in light of countervailing considerations such as the significant societal interests in granting to citizens these constitutional protections and perhaps in reining in legislative and executive discretion? Should all constitutional rights be treated alike? Even protected trial rights? For example, is there a constitutionally significant difference between the right to a jury trial, which one may lose only through knowing and intelligent waiver; the right not to be unconstitutionally searched and seized, which can be forfeited by failure to invoke the exclusionary rule; and rights such as protection against cruel and unusual punishment, which courts presumably would raise on their own? ${ }^{14}$ Should the waiver doctrine apply at all when the party has raised a federal constitutional issue that is identical or nearly identical to the state constitutional provision? What possible reason can justify waiver of the state claim when the raised federal constitutional provision would put the trial judge on notice of the parallel state provision-one that might offer greater protection? ${ }^{15}$ Under what circumstances may or must the high court excuse the failure to raise the issue?

We are admonished that the adversary system demands the application of the waiver doctrine for the failure to raise these state issues at the trial level. We hail the parties' rights to conduct the litigation in the manner they see fit. Litigant autonomy through party presentation must not be sacrificed. And it matters not whether counsel's failure to raise the issue came about through choice or pure oversight.

There is also the firmly held belief that judicial issue creation casts the judges in a different role, one to which they are unaccustomed. Judges prefer the traditional passive role rather than an active one. ${ }^{16}$ After all, they are supposed to be neutral; by choosing to point out or

14. Some protections in the state constitutions do more than just create an individual liberty or property interest. For example, the proscription against cruel and unusual punishment limits legislative prerogative to adopt barbaric practices. In such cases it should not matter whether the defendant raises an objection. Should a defendant be put to death when counsel fails to adequately explore mitigating circumstances? See supra note 6 . There are factors that should be considered in determining whether the waiver should be excused-even when a defendant knowingly and intelligently refuses to object. For further discussion, see infra notes 61-63 and accompanying text.

15. Unless, of course, the state high court had previously refused to extend greater protections under the particular provision of the state constitution.

16. Contrast the American approach with the inquisitorial system in which the judge takes a very active role in all phases of the proceeding. See Frost, supra note 9, at 459-60 (describing the inquisitorial system as “judge-dominated”); Ellen E. Sward, Values, Ideology, and the Evolution of the Adversary System, 64 IND. L.J. 301, 302 (stating that the adversary system is characterized by a “passive decisionmaker”). 
consider an issue favorable to a defendant, they may be cast in the role of a protagonist or advocate. And then follows the parade of horrors! Should these same judges offer advice to the prosecution that may tilt the scales in its favor?

Many believe that the passive model furthers procedural fairness. As Sarah Cravens has observed:

It works on the assumption that a good process is the best way to achieve good and fair results. If all of the procedural standards are met, everything should have been done correctly, and that affords the best possibility of getting to the truth, and ultimately to the best "correct" answer. A judge who interferes with the process by stepping out of the role of umpire and into the role of adversarial participant by becoming involved in the fashioning of arguments may risk upsetting the process and producing bad results. ${ }^{17}$

One may also inquire why there is any issue at all with respect to the interpretation of state constitutional law if the United States Supreme Court has already spoken on the identically or nearly identically worded guarantee contained in the federal counterpart. The answer to this inquiry requires an understanding of our federalist system. The original Federal Bill of Rights contained rights that were protected only from federal interference. ${ }^{18}$ So for the early period in our history, state constitutions served as the main source of fundamental guarantees of individual liberties. ${ }^{19}$ These state constitutional rights were enforced by

17. Cravens, supra note 9, at 269. Of course, Cravens assumes that the adversary model seeks or achieves truth. As Cravens also recognizes, the value of process may obscure a more "substantively superior result." Id. at 269-70. When these values clash, the court must decide which model to adopt. Herein lies the difficulty. This Essay adopts the liberal model of excusing waiver when defense counsel fails to raise state constitutional issues that may be dispositive of criminal cases. It may have no application to ordinary civil disputes in which litigants may actually have valid reasons for not raising issues. For example, a litigant may wish to avoid issue preclusion, reserving the resolution of the issue to another proceeding, sometimes in a more favorable venue. It is unlikely that counsel in most criminal cases-other than perhaps white collar crimes-deliberately choose not to raise constitutional concerns. However, it is possible that even these choices may be deliberately made. For example, the defendant may choose not to move to exclude evidence on the ground of illegal search and seizure in the hopes of later bringing a claim against the police officers under the Civil Rights Act, 42 U.S.C. § 1983 (2006). See Allen v. McCurry, 449 U.S. 90, 105 (1980) (holding that criminal court's finding of no illegal search and seizure precludes action against police officer for violating the Fourth Amendment). But these waivers of defenses in serious criminal cases in order to reserve issues for later civil proceedings are likely quite rare.

18. See Barron v. City of Baltimore, 32 U.S. 243, 250-51 (1833) (holding that a provision in the Bill of Rights restricts only the power of the federal government).

19. See Brennan, supra note 1 , at 501-02. 
state courts. $^{20}$ In construing their constitutional provisions, the state courts examined opinions from other jurisdictions, including United States Supreme Court cases, but they were free to give greater protection to the rights guaranteed under the state constitution, or little if any protection to rights not protected by the Federal Constitution. In the 1960s, the Supreme Court began to selectively incorporate many of the federal rights contained in the Bill of Rights through the Fourteenth Amendment, thus granting criminal defendants and others rights against sovereign states that they could raise defensively. ${ }^{21}$ Although these were minimum guarantees that could not be narrowed by application of state law, there appeared to be no sound reason for not tendering the state defense on the state constitution and seeking greater protections. ${ }^{22}$ But for some unknown reason, counsel often deferred to the Federal Constitution, argued exclusively about the meaning and scope of Supreme Court interpretation, and failed to recognize or point out the distinct role of the state guarantees. Would counsel also hesitate to raise the state claim where the applicable Bill of Rights provision had not been incorporated through the Fourteenth Amendment's Due Process

\footnotetext{
20. See id.

21. At an earlier time, the Court required states to enforce minimal standards directly under the Due Process Clause of the Fourteenth Amendment. See, e.g., Rochin v. California, 342 U.S. 165, 209-10 (1952) (holding that forcibly extracting the contents of defendant's stomach to obtain evidence violated the Fourteenth Amendment's Due Process Clause); Powell v. Alabama, 287 U.S. 45, 71 (1932) (holding that in a capital case, the state's failure to appoint counsel for defendant violated the Fourteenth Amendment's Due Process Clause). Of course, nothing prevents a state court from giving greater protections to parties under the state due process clause. In the context of personal jurisdiction in civil cases, states may be more protective of nonresidents or of transients who are served within the state. States, too, may give greater protection to debtors against attachment or seizures of their property than is required under the Federal Constitution. For example, the state may reject the rationale of Mitchell v. W.T. Grant Co., 416 U.S. 600, 609-10 (1974) (permitting seizure of a debtor's property without notice as long as the debtor has the opportunity for an immediate post-deprivation hearing). Instead the state could require preattachment notice and an opportunity to be heard in all cases, as is presumably still required in wage attachment under the Federal Constitution. See Sniadach v. Family Fin. Corp. of Bay View, 395 U.S. 337, 348 (1969) (Harlan, J., concurring). In the double jeopardy context there is no reason to suppose that states must permit a successive criminal case after a transactionally related federal criminal case against the same defendant has been completed.

22. Perhaps counsel believed that the state high court would use a lockstep approach, so that it would be futile to seek additional protection. For discussion of lockstep, primacy and interstitial approaches to interpretation of parallel state constitutional protections, see Stanley G. Feldman \& David L. Abney, The Double Security of Federalism: Protecting Individual Liberty Under the Arizona Constitution, 20 ARIZ. ST. L.J. 115 (1988); Paul Marcus, State Constitutional Protection for Defendants in Criminal Prosecutions, 20 ARIZ. ST. L.J. 151 (1988); Ruth V. McGregor, Recent Developments in Arizona State Constitutional Law, 35 ARIz. ST. L.J. 265 (2003).
} 
Clause $?^{23}$ Moreover, would counsel cower if the Supreme Court had restrictively interpreted these nonincorporated provisions in protecting individuals against federal interference? And what about those situations in which there is no corresponding federal right whatsoever? ${ }^{24}$

Perhaps a bit of history may assist. Before the 1950s, federal courts were rather restrictive in determining the scope of the Bill of Rights which, as we have already noted, only protected against federal interference with rights. ${ }^{25}$ So, it should not come as any surprise that state constitutional provisions often expressly broadened the protections to persons subject to the jurisdiction of state courts. And what was not expressly set forth in the language of the state constitution could be crafted by judicial implication. Any Federal Supreme Court decision that limited the scope of the federal right would not prevent the state from granting greater protections. ${ }^{26}$ For example, when the people approved the Arizona Constitution in 1911, it contained greater privacy protections than those contained in the Bill of Rights. ${ }^{27}$ And Arizonans always had the right to bear arms for their own defense. ${ }^{28}$ They did not have to await decisions on the Second Amendment granting rights to

23. The Indictment Clause of the Fifth Amendment has not been applied to the states. See Hurtado v. California, 110 U.S. 516, 538 (1884). Nor has any Supreme Court case applied the Excessive Fines Clause to the states. Cf. Murphy v. Hunt, 455 U.S. 478, 480-81 (1982) (vacating excessive bail claim because of mootness following conviction in state court). The Court has not addressed the venue provisions of the Sixth Amendment. See K. Winchester Gaines, Race, Venue, and the Rodney King Case: Can Batson Save the Vicinage Community?, 73 U. DET. MerCy L. Rev. 271, 289-90 (1996). And in civil cases the Seventh Amendment right to a jury trial has not been extended to the states. Olesen v. Trust Co. of Chi., 245 F.2d 522, 524 (7th Cir. 1957). All of these guarantees can certainly be accorded to the parties under state law.

24. Many state constitutions explicitly provide a right to privacy. See, e.g., ALASKA CONST. art. I, § 22; ARIZ. CONST. art. II, § 8; HAW. CONST. art. I, §§ 6-7; WASH. CONST. art. I, § 7.

25. See supra note 18 and accompanying text.

26. See Prune Yard Shopping Ctr. v. Robins, 447 U.S. 74, 81 (1980).

27. Compare ARIZ. CONST. art. II, § 8 ("No person shall be disturbed in his private affairs, or his home invaded, without authority of law." (emphasis added)), with U.S. CONST. amend. IV ("The right of the people to be secure in their persons, houses, papers, and effects, against unreasonable searches and seizures, shall not be violated ....”).

28. See ARIZ. CONST. art. II, § 26 ("The right of the individual citizen to bear arms in defense of himself or the state shall not be impaired, but nothing in this section shall be construed as authorizing individuals or corporations to organize, maintain, or employ an armed body of men."). There are, of course, major linguistic differences between this section and the Second Amendment to the U.S. Constitution, which ties the right to bear arms to the maintenance of a militia and extends the right to the people, rather than directly to individuals. See U.S. CONST. amend. II ("A well regulated Militia, being necessary to the security of a free State, the right of the people to keep and bear arms, shall not be infringed.”). Arizona's constitution also guaranteed women the right to vote eight years before the passage of the Nineteenth Amendment. See ARIZ. Const. art. VII, § 2 (amended in 1912). 
bear arms to the people of the United States and binding the states through the selective incorporation doctrine. ${ }^{29}$

Starting in the 1960s, several important developments occurred at the federal level that bear directly on the theme of this Essay. First, as already noted, through the doctrine of selective incorporation, many of the provisions of the original Bill of Rights became obligatory on the states. $^{30}$ They imposed minimum standards. In other words, states could not give lesser protection to persons than the protections required under the Federal Constitution. But it was often forgotten that states could, through their own constitutions, grant greater protection than those accorded under the federal scheme. ${ }^{31}$ During this same period, the Supreme Court aggressively expanded the protections afforded under the Bill of Rights. ${ }^{32}$ One unintended consequence developed - that is, state courts became less inclined to resort to their own state constitutions for vindication of rights. ${ }^{33}$ They fell "into the drowsy habit of looking no further than federal constitutional law." ${ }^{34}$ As long as protection was afforded to the defendant, it mattered little whether it was based on state or federal law. ${ }^{35}$ But in the 1970s, the Supreme Court started to cut back on the scope of federal guarantees. ${ }^{36}$ Academics and judges sounded the hue and cry! Rely on your state declaration of rights! Lawyers should have switched gears and raised the state guarantee, but at first few were prepared. Thirty years later, the deplorable situation persists, ${ }^{37}$ despite

29. See McDonald v. City of Chicago, 130 S. Ct. 3020, 3050 (2010) (holding that the Second Amendment right is fully applicable to the states). Should the Supreme Court at some time in the future restrict the right to bear arms, it would not and should not have any effect on what clearly appears to be the broader protection of the Arizona Constitution.

30. See supra note 21 and accompanying text.

31. See PruneYard Shopping Ctr., 447 U.S. at 81.

32. See Jeffrey Omar Usman, Good Enough for Government Work: The Interpretation of Positive Constitutional Rights in State Constitutions, 73 ALB. L. REV. 1459, 1459-60 (2010). As Jeffrey Usman observed: "With the dynamic constitutional change brought about by the Warren Court, state constitutionalism became an afterthought, relegated at best to a secondary consideration, when not entirely forgotten. All of the oxygen of constitutionalism was sucked out of the state constitutions and breathed into the Federal Constitution.” Id. at 1491 (footnote omitted).

33. Id.

34. Id.

35. Unless, of course, the Supreme Court reviewed and reversed the judgment on the basis of the federal ground. See Michigan v. Long, 463 U.S. 1032, 1038 n.4 (1983). And even then, the state court on remand may base the decision on the state ground, which could then be insulated from review under the doctrine of Michigan $v$. Long. See id.

36. See Usman, supra note 32, at 1459-60. Since then, the process of retrenchment has proceeded inexorably. See Bonventre, supra note 1, at 846-47.

37. See supra note 1 and accompanying text. 
the fact that many persons may be entitled to receive greater protection of their individual rights through application of rights derived from the state constitutions.

So why then has there not been greater development of state constitutional law? After all, we have recognized the desirability of focusing on state constitutional provisions at least since the mid-1970s, starting with Justice Brennan's landmark article. ${ }^{39}$ In large part it involves the failure of counsel to appreciate the independent role of state constitutions and the refusal of the judiciary to excuse the waiver of state

38. See Arthur L. Burnett, Sr., An Irony: Greater Protection of Individual Rights Now Found in State Courts, 22 CRIM. JUST. 20 (2007) (examining cases where state courts have departed from federal jurisprudence in the following areas: search and seizure, Fifth Amendment incrimination and due process, double jeopardy prohibition, right to counsel, and cruel and unusual punishment). Burnett concluded:

We have attempted to present a broad enough survey of such cases as to sensitize members of the criminal defense bar that the time has come for lawyers to invoke state constitutional rights as aggressively as they have asserted federal constitutional rights in the past, and to do so early in the case proceedings in order to protect their clients from lengthy incarceration and the anxiety of the appeals process, and to conserve valuable judicial resources. These efforts should not be viewed only as a [sic] benefiting the guilty, but, more importantly, as a deterrent to unlawful police conduct, as promoting higher quality law enforcement through more effective training, as enhancing the integrity of judicial proceedings, and as protecting the privacy and liberty interests of the countless innocent individuals who are never vindicated because they lack the resources to bring a civil suit when over-zealous police find no incriminating evidence.

Id. at 27.

In addition, strict application of the waiver doctrine impedes the role of judicial oversight of government encroachment on cherished individual liberties. For reasons specifically applicable to the cruel and unusual punishment provisions, see infra notes 47-60 and accompanying text.

39. Brennan, supra note 1; see also Paul W. Kahn, Interpretation and Authority in State Constitutionalism, 106 HARV. L. REV. 1147, 1147 (1993); Jack L. Landau, Hurrah for Revolution: A Critical Assessment of State Constitutional Interpretation, 79 OR. L. REV. 793, 809-10 (2000).

One scholar had this to say:

Largely dormant during the Warren Court years, state constitutionalism has reemerged under the moniker of judicial federalism, though its practice by state courts is intermittent and inconsistent. If the original sin of judicial federalism is Justice Brennan's politicized end-run around the Burger court, the debate over the application of state constitutionalism has not escaped this taint. The primary focus in discussing judicial federalism remains on the propriety of divergent interpretations of state constitutional provisions that correspond with federal constitutional rights. Despite Justice Brennan's appeal . . . state courts have become quite accustomed to the security of federal constitutional precedent. When given the opportunity to strike out in a different direction, state courts instead, generally, engage in a lock-step analysis with federal courts.

Usman, supra note 32, at 1492-93 (footnotes omitted). No wonder, then that the state tribunals often refuse to excuse the waiver of state constitutional rights. According to Usman, state courts should at the very least welcome the opportunity to forge and define state constitutional rights when no corresponding federal right has already been judicially defined. Id. at 1494. 
constitutional rights. Justice Feldman and David Abney addressed these issues as follows:

Perhaps part of the fault is that of the bar, which all too frequently seems to base arguments solely upon federal provisions and federal decisional law, ignoring state provisions even though the plain text would seem to support the position for which the lawyer argues.

In the final analysis, however, the fault is judicial. All Arizona jurists take an oath binding them to support the constitution and laws of the state of Arizona as well as those of the United States. It is their duty and obligation to give due consideration to the Arizona Constitution, at least when lawyers have made an adequate record and raised the proper arguments. ... If our jurisprudence is not to become result-oriented, judges must at least consider the questions raised by unique language. Among the questions: Why did the framers not use the same language as the federal version? Where did our version come from? What has the state of origin done with the same language? What are past reasons for not giving effect to the plain words of Arizona organic law? Is there room for "interpretation?"40

A more fundamental question remains. Even if the language of the provisions is identical, ${ }^{41}$ why should the state courts follow the decisions of the U.S. Supreme Court that appear to them too restrictive of fundamental rights, wrongly decided, or not within the contemplation of the framers of the state's declaration of rights? Why should state courts defer to opinions of a badly fractured Supreme Court when interpreting state constitutional provisions unless the state high court agrees with the majority's reasoning? In other words, what is so improper about using the state constitution as the primary source in defining the scope of an individual's civil rights and liberties and in cabining the discretion of the

40. Feldman \& Abney, supra note 22, at 146. In addition to blaming the bar, we must attribute some blame to law schools as well. For many years, law schools did not offer courses in state constitutional law. And although some have now adopted courses, few require students to take them. Contrast that treatment with the requirement of taking one or more separate and distinct courses in federal constitutional law. The movement toward a national bar examination also will have the effect of deemphasizing the study of state constitutional law.

Additionally, Feldman and Abney's point about making the proper arguments should not be read as precluding review of unraised issues.

41. There are rare occasions when the litigant fails to raise the federal constitutional issue in the appellate courts and relies exclusively on parallel state provisions. See State v. Noble, 829 P.2d 1217, 1219 n.4 (observing that analysis of ex post facto laws under both constitutions is the same, and thus there is no need to consider the effect of failure to raise the federal claim in the court of appeals). 
state legislative and executive branches? ${ }^{42}$ And, assuming that the opinion of the state court may be rationally articulated, what is so wrong about a result-oriented approach?

In the 1970s, Justice Brennan, noting the end of expansionist interpretation of federal constitutional rights by the U.S. Supreme Court, championed state constitutional guarantees as the source of individual rights. $^{43}$ Numerous state court decisions have since adopted this approach, rejecting the restrictive interpretation of federal guarantees. ${ }^{44}$ But according to some scholars, many of these decisions are purely "reactive," merely disagreeing with the Supreme Court pronouncement and holding with little or no analysis or reasoning that the state constitutional protection affords broader relief. ${ }^{45}$ Other scholars support reactive decisions that highlight the flaws in the Supreme Court decisions and that may cause the Court to change its position in later cases. ${ }^{46}$

42. Professor Tarr contends that "too many states continue to rely automatically on federal law when confronted with rights issues.... [T]oo many frame their analysis in federal doctrinal categories, making state constitutional law merely a poor relation, stuck with ill-fitting hand-me downs.” G. Alan TARr, Understanding State Constitutions 208 (1998). Perhaps this explains why so many practitioners fail to raise state constitutional issues.

43. See Brennan, supra note 1 , at 489-91.

44. Although many lawyers in the criminal defense bar fail to raise state law constitutional claims, others have been more diligent. See 2 JENNIFER FrIESEN, StATE CONSTITUTIONAL LAw: LiTIGATING INDIVIDUAL RIGHTS, CLAIMS AND DEFENSES § 11.01 (3d ed. 2000) ("[Since the 1970s there has been] an exponential increase in the number of opinions rendered by state supreme courts interpreting state constitutional prohibitions on unreasonable searches and seizures.”); Shirley S. Abrahamson, Criminal Law and State Constitutions: The Emergence of State Constitutional Law, 63 TEX. L. REV. 1141, 1148-51 (1985). But see supra note 1.

Many variables enter into the determination whether counsel will raise a state constitutional ground in any particular case. They include the following: counsel's awareness that there is a potentially helpful state issue at all; counsel's belief in the strength of the federal and other defenses; the treatment that has been accorded state constitutional rights in other decisions; counsel's understanding of whether the lockstep approach will be adopted in the interpretation of the parallel provision in her case; counsel's previous success with the presentation of the state law constitutional claims; counsel's willingness to research the area in the face of all other pressing needs of the case and other matters; the insistence of the trial court that counsel develop the state issue; the demands of the appellate courts that counsel address the issues; an understanding of the sanctions that may be imposed if counsel fails to raise the state issue; and the professionalism concerns that are raised if counsel waives a valuable right without receiving any benefit whatsoever.

45. See Lawrence Friedman, Reactive and Incompletely Theorized State Constitutional Decision-Making, 77 Miss. L.J. 265, 266 (2007).

46. See James A. Gardner, State Constitutional Rights as Resistance to National Power: Toward a Functional Theory of State Constitutions, 91 GEO. L.J. 1003, 1033 (2003) (arguing that state decisions rejecting Supreme Court precedents on individual rights may check the Court's national power); Leigh A. Morrissey, Special Project, State Courts Reject Leon on State Constitutional Grounds: A Defense of Reactive Rulings, 47 VAND. L. REV. 917, 940 (1994). 
A recent Arizona case ${ }^{47}$ graphically illustrates several of the problems alluded to in this Essay. ${ }^{48}$ Morton Berger was sentenced to a term of two hundred years - ten years for each count-for possession of twenty photos of child pornography. ${ }^{49}$ By statute, each count had to be served consecutively, without possibility of parole, pardon, or commutation. ${ }^{50}$ This was the minimum sentence the court could impose for conviction of possessing the twenty photographs. The Court of Appeals and Supreme Court of Arizona affirmed the conviction and sentence, rejecting Berger's argument that the sentence violated the Cruel and Unusual Punishment Clause contained in the Eighth Amendment to the U.S. Constitution. ${ }^{51}$ Certiorari to the U.S. Supreme Court was denied. ${ }^{52}$ Thereafter, post-conviction relief proceedings in the Arizona court system proved unavailing. The case is currently pending in federal court on habeas review.

The case involved possession-and only possession-of child pornography. ${ }^{53}$ As stated in Berger's petition for post-conviction relief, "[T]he defendant never had any contact with any of the children involved, ${ }^{54}$ never told anyone about what he was doing, never shared the materials with anyone, and was never involved with the people who make a profit from these acts." 55 Over the years, he downloaded,

47. State v. Berger, 134 P.3d 378 (Ariz. 2006).

48. I have assisted Berger's counsel on a pro bono basis in connection with federal habeas proceedings that are still pending. Only federal issues, including ineffective assistance of counsel claims, are considered in this venue. Thus, in connection with the Sixth Amendment ineffective assistance of counsel claim, the federal court may consider the obligation to preserve the state constitutional issue in the Supreme Court. Chief Justice Rebecca White Berch of the Arizona Supreme Court participated in the Berger decision. She did not opine on the matters discussed in this essay - that is, the role of the courts in considering unraised issues of state constitutional law.

49. Id. at 379.

50. Id. (citing ARIZ. ReV. StAT. ANN. § 13-604.01 (West 2008) (renumbered as § 13-705 (West 2010)).

51. Id. at 380, 388 .

52. Berger v. Arizona, 549 U.S. 1252 (2007).

53. See Berger, 134 P.3d at 393 (Berch, J., concurring in part and dissenting in part).

54. It appears that the photographs of foreign children on foreign soil were taken decades before Berger's possession. Indeed, Berger's original possession of the photographs would probably not have been a felony in most states. Further, "in less than one generation" what was a relatively minor offense in Arizona has been changed to a longer than life sentence. Petition for Post Conviction Relief at 5-6, State v. Berger, No. CR 2002-013657 (Ariz. Super. Ct. June 26, 2007). Also noteworthy is the fact that convicted murderers often receive lighter sentences than Berger. See id. at 10-11. And we do not know which criminal laws, if any, the perpetrators of these incidentsthose who photographed, distributed, and profited from the transmission of these pornographic images - violated in these foreign venues.

55. Id. at 5 . 
catalogued, and collected hundreds, if not thousands of photographs. ${ }^{56}$ Yet, there was no evidence that he ever paid consideration. ${ }^{57}$ Until the conviction in this case, Berger was considered a model citizen. ${ }^{58}$

Berger raised a federal cruel and unusual punishment claim to resist the imposition of the two hundred-year sentence. ${ }^{59}$ He specifically raised Arizona's constitutional protection against cruel and unusual punishment, but he did not pursue that avenue in the Supreme Court of Arizona. ${ }^{60}$ This is most perplexing in view of several factors that should have been known to counsel. First, federalism concerns carefully cabin federal intrusion into state sentencing practices. There are few cases, outside death penalty matters, ${ }^{61}$ in which the Court has vacated a sentence on the grounds of the cruel and unusual provision. ${ }^{62}$ And there are very few such pleas based on the federal cruel and unusual punishment provision. ${ }^{63}$ The latest case, upholding a "three strikes and

56. Berger, 134 P.3d at 380.

57. Id. at 393 (Berch, J., concurring in part and dissenting in part).

58. Brief of Amicus Curiae: The American Civil Liberties Union of Arizona at 3, State v. Berger, 134 P.3d 378 (Ariz. 2006) (No. CR 05-0101-PR), 2005 WL 3965947 at *3.

59. Berger, 134 P.3d at 380 .

60. State v. Berger, 103 P.3d 298, 300 (Ariz. App. 2004) (noting that Berger argued article 2, section 15 of the Arizona Constitution before the trial court), vacated in part by 134 P.3d 378 (Ariz. 2008).

61. See supra note 6.

62. See, e.g., Trop v. Dulles, 356 U.S. 86, 101 (1958) (holding that denationalization as a punishment is prohibited by the Eighth Amendment); Weems v. United States, 217 U.S. 349, 382 (1910) (holding that hard and painful labor constituted cruel and unusual punishment); $c f$. Hope v. Pelzer, 536 U.S. 730, 738 (2002) (holding that inmate was subjected to cruel and unusual punishment when prison guards handcuffed him to a hitching post); Solem v. Helm, 463 U.S. 277, 303 (1983) (holding that life imprisonment without possibility of parole was cruel and unusual punishment for defendant convicted of passing a \$100 bad check).

There has been some movement lately to expand the federal cruel and unusual punishment provision. In May 2010, the Supreme Court struck down life-without-parole sentence for juvenile offenders who did not commit homicide unless the state provided "some meaningful opportunity to obtain release.” Graham v. Florida, 130 S. Ct. 2011, 2016 (2010). Yet in January 2011, the Court unanimously reversed the Ninth Circuit and refused to interfere with a state parole board's decision not to release a person sentenced to a life term. Swarthout v. Cooke, 131 S. Ct. 859, 863 (2011).

63. See, e.g., Rummel v. Estelle, 445 U.S. 263, 285 (1980) (holding that under habitual offender statute, a sentence of life with possibility of parole for theft by false pretenses was not unconstitutional). In Rummel, the defendant had two prior convictions for fraudulent use of credit card and for passing a forged check. Id. at 265-66. The total value of property amounted to less than \$250. Id. The Court held that life imprisonment for the three crimes was not extreme, stating "one could argue without fear of contradiction by any decision of this Court that for crimes classified and classifiable as felonies... the length of the sentence actually imposed is purely a matter of legislative prerogative." Id. at 274. As an example of such an extreme case, the Court cited a legislature's decision to make overtime parking a felony punishable by life imprisonment. Id. at 274 n.11. Three years after Rummel, the Court took another turn, this time holding unconstitutional a 
you're out" sentencing statute, went fairly far in abandoning defendants to the whims of state legislatures. ${ }^{64}$ Moreover, Harmelin v. Michigan, the purportedly controlling case, was a badly fractured opinion with Justice Kennedy deciding the case on the narrowest ground, ${ }^{65}$ which therefore made his concurring opinion controlling. ${ }^{66}$ It contained the language that has been received as the voice of Supreme Court jurisprudence in this area. ${ }^{67}$ It is indeed unfortunate when a single Justice binds the federal and state courts to the meaning of the Federal Constitution. But while that perhaps forms the basis of our federal jurisprudence, why should state courts blindly obey the one-Justice interpretation when construing a parallel state constitutional provisionunless, of course, the state court agrees with the reasoning?

Under these circumstances one may properly wonder why one would abandon any grounds for relief in the Arizona Supreme Court based on an independent body of law. ${ }^{68}$ Moreover, astute counsel would have realized the precarious position he faced should the state courts have

mandatory sentence without possibility of parole for passing a bad check for $\$ 100$. Solem, 463 U.S. at 303. The defendant in Solem had three prior convictions for nonviolent crimes. Id. at 279-80. The five Justices in the majority expressly adopted a "deeply rooted" principle of proportionality in ordinary non-capital cases. Id. at 284. The Court adopted the three-factor test used in the Rummel dissent. Id. at 290-92; see also Rummel, 445 U.S. at 295 (Powell, J., dissenting). It looked to objective criteria of the gravity of the offense and the severity of the penalty; the sentences imposed for other crimes in the same jurisdiction; and the sentences imposed for the same crime in other jurisdictions. Solem, 463 U.S. at 290-92. Finally in Harmelin v. Michigan, 501 U.S. 957 (1991), the Court, failing to produce a majority opinion, upheld a life sentence without possibility of parole for possession of 650 grams of cocaine. Id. at 994-95. Two Justices would have abandoned the proportionality test in non-capital cases. See id. at 957 (Justices Scalia and Rehnquist). Writing for the three-member concurrence, Justice Kennedy would have applied only the first factor of the Solem test and would only reach the other two in the rare case where the sentence imposed leads to an inference of gross disproportionality. Id. at 1004-05 (Kennedy, J., concurring). According to the concurrence, this was not such a rare case. See id. at 1005 . One can certainly perceive the difficulty in predicting how Berger would come out using the Kennedy test. Under these circumstances it seems foolhardy not to raise the state constitutional issue, regardless of the similarity of the wording of the provisions.

64. Ewing v. California, 538 U.S. 11, 28-29 (2003). Justice O’Connor's plurality opinion, the most restricted view of a fractured court, tracks Justice Kennedy's test in Harmelin. Id. at 23-24.

65. Harmelin, 501 U.S. at 1008-09 (Kennedy, J., concurring).

66. See Gregg v. Georgia, 428 U.S. 153, 169 n.15 (1976) (noting that the most restricted view becomes the court's opinion).

67. See supra note 63.

68. Arizona cases had, prior to Harmelin and Ewing, used the "shock the conscience of society" test, requiring punishment "overly severe or disproportionate to the crime" in Eighth Amendment jurisprudence. See, e.g., State v. Davis, 79 P.3d 64, 75 (Ariz. 2003). While that test had been rejected in favor of the "gross disproportionality test" set forth in Harmelin and Ewing, perhaps the rejected "overly severe or disproportionate to the crime" test would be resurrected in giving life to the Arizona Constitution. 
granted relief solely based on the federal provision. U.S. Supreme Court review would be more than a bare possibility — with override being more than academic. ${ }^{69}$ So what should counsel do in these situations? The answer is clear-raise the state issue explicitly and brief it adequately. ${ }^{70}$ Admittedly, counsel faces a hurdle. The state and federal provisions contain identical language. Indeed, the Washington constitutional provision, ${ }^{71}$ the state from which many of Arizona's rights and liberties guarantees were adopted, was rejected by Arizona courts in favor of the more restrictive federal model. ${ }^{72}$ Perhaps counsel believed that the state courts would adopt the lockstep method of interpretation. ${ }^{73}$ But this fails to take into account a number of circumstances. A clear resolution of the case on the state ground would be considered adequate and independent, precluding Supreme Court review of the federal question. ${ }^{74}$ Nothing requires a lockstep approach. The federal provision was enacted in 1791; the state provision in 1911. A state court need not adopt the federal interpretation if it deems that analysis unacceptable in interpreting its own constitution. ${ }^{75}$

Perhaps counsel was misled by its reading of a footnote in another state case. ${ }^{76}$ In State v. Davis, counsel was requested to brief the law on the Arizona cruel and unusual punishment clause. ${ }^{77}$ However, he

69. Clearly the role of the Supreme Court has significantly changed in the past decades. As one scholar has aptly stated:

No longer are the cases from the state courts predominantly, or even typically, those where the Supreme Court determines that the states have failed to protect rights and liberties sufficiently. By contrast, the cases today are regularly those where the Court

finds fault with the state courts for protecting rights and liberties too much. Bonventre, supra note 1, at 846-47.

70. Even if the issue is raised, courts may consider the defense waived if it is not adequately briefed. State v. Arthur H., 953 A.2d 630, 643-44 (Conn. 2008) (noting that failure to provide independent analysis of the state constitutional issue limits the court's consideration to the Federal Constitution); cf. State v. Jewett, 500 A.2d 233, 238-39 (Vt. 1985) (requiring rebriefing on a state constitutional issue).

71. WASH. CONST. art. I § 14 (banning "cruel” punishments with no mention of "unusual” ones).

72. See State v. Thorne, 921 P.2d 514, 531 (Wash. 1996) (noting that the Washington provision affords broader protection than the U.S. Constitution).

73. See supra note 22.

74. See Michigan v. Long, 463 U.S. 1032, 1040-41 (1983).

75. See id. at 1040.

76. See State v. Davis, 79 P.3d 64, 71 n.4 (Ariz. 2003) (“'[W]hen later opinions of the Supreme Court show our constitutional interpretations to be incorrect, we must overrule them and bring our decisions into conformity with Supreme Court precedent.”).

77. Id. at 67-68. This is exactly the approach the Arizona Supreme Court should have taken in Berger. Counsel's response, however, was questionable: 
Davis argues that given the circumstances of his offenses, the four flat, consecutive, thirteen-year sentences violate the prohibition against cruel and unusual punishment found in the Eighth Amendment to the United States Constitution and Article 2, Section 15 of the Arizona Constitution. He contends that the mandatory fifty-two-year sentence, without the possibility of parole, is so grossly disproportionate to his offenses as to be unconstitutional.

We asked the parties to brief whether Article 2, Section 15 of the Arizona Constitution provides greater protection against cruel and unusual punishment than does the Eighth Amendment to the United States Constitution. Although we do not follow federal precedent blindly, after considering the issue we do not find in this case a compelling reason to interpret Arizona's cruel and unusual punishment provision differently from the related provision in the federal constitution.

Id. (citations omitted).

The type of construct that is the basis for sound constitutional argument initially develops during the first-year curriculum of law school. See Kris Franklin, Theory Saved my Life, 8 N.Y. City L. REV. 599, 607-08 (2005). Yet when it comes to raising, briefing, and arguing state constitutional law, my optimism ends. A comparison of the federal and state systems may more realistically advance the reasons for this pessimism. Let us first examine the federal system. Just about every lawyer that litigates in that system has been fully immersed in federal constitutional law. A moment's research will probably uncover a score of opinions and scholarly articles on even the more abstruse points of law. The dialogue among the circuits would probably be sufficient, even if minimally, for a competent legal analysis on non-garden-variety issues of federal law. And the higher up one climbs on the hierarchy of federal courts, the more attorneys would willingly lend a helping hand. Just a quick review of the academics who specialize in federal constitutional law would certainly buttress this proposition. And there are numerous think tanks and other resources in the federal arena that will willingly lend a hand to advance the cause. The cachet that is gained by such participation at the federal appellate levels cannot be minimized. It is reason enough for involvement with the making of federal constitutional law. Note, too, that participation by well known constitutional lawyers at the federal district court level is perhaps the wave of the future. See, e.g., Perry v. Schwarzenegger, 704 F. Supp. 2d 921, 926 (N.D. Cal. 2010) (listing David Boies and Theodore B. Olson as counsel).

Compare the above with what is happening at the state level. Except for a few states, New York, California, and Massachusetts included, where is the cadre of state constitutional law experts that may come to the aid of the individual litigant? How many practicing lawyers and lawyeracademicians fit into the category of state law specialists? Even were they to develop that expertise, what cachet for arguing in the states' highest courts compares with rendering arguments at the appellate level of the federal system? And we must also always remember that the raising of the state issue in the first place ordinarily rests with the counsel at the lower levels who is beleaguered with other duties and responsibilities even in the very case that has the state constitutional issue hidden beneath its surface.

One other matter should not go unnoticed. What obligation does the office of the state Attorney General have to raise issues of state constitutional law—or any law for that matter- that may favorably incline to the benefit of a criminal defendant? Is the Attorney General solely an advocate on the side of the prosecution whose only responsibilities to the criminal defendant relate to strict adherence to the Rules of Professional Responsibility and to fundamental but minimal procedural due process protections? Or, as her oath would seem to dictate, is she the champion of the constitution and laws as well? An example should suffice. Let us return to the Berger case and approach the question from a different perspective. See supra notes 47-60 and accompanying text. First, assume that defense counsel did not raise the state constitutional issue in the lower courts. Should the Solicitor General research the subject anyway? Should she alert the court and the defense counsel of her opinion on the matter if there is a colorable argument that the clause forbids imposition of the mandatory minimum sentence? Should she instead urge the lockstep approach and 
eventually won in the state court on the basis of the federal provision. ${ }^{78}$ Rather than approaching Davis from the standpoint of its favorable impact on the interpretation of the federal provision under the facts of that case and disregarding the passage, counsel for Berger might have improperly read the passage to bar the state inquiry. Indeed, the intermediate court's dismissal of the state claim in Berger and its reliance on the stated passage may have been the basis for counsel's abandonment of the state claim at the state supreme court level. Such a reading with so much at stake is inexcusable.

Berger presented a case of first impression to the Arizona Supreme Court: application of statutorily mandated consecutive sentences for separate criminal offenses that in reality formed the nucleus of hundreds, if not thousands of similar crimes; that is, possession of child pornography. ${ }^{79}$ No Supreme Court case had touched upon that issue. The closest analogy, Ewing, ${ }^{80}$ appeared distinguishable. In that case, the defendant had previously been convicted of two crimes. ${ }^{81}$ He was therefore considered a habitual offender. ${ }^{82}$ It would be a great leap to apply the holding of that case to Berger, where the defendant had not previously had any run-in with the law. But the state court made the leap, never mentioning the state law issue.

The Arizona Supreme Court felt bound to apply the federal "disproportionality" test to each separate offense, rather than to the total sentence imposed for the conviction of possession of twenty photographs. $^{83}$ The court held ten years for the possession of a single

thereby take no responsibility for the independent development of state constitutional law? Should she confess error in the case, thereby jeopardizing her political career? These are of course very difficult decisions.

I do not suggest that our public servants have shirked their duty. In fairness, I should allude to the courage of state law judges who interpret state constitutions in a manner that riles the people. In November 2010, the Iowa voters failed to retain three supreme court justices after they joined in a unanimous opinion of the court nullifying a state law preventing gay marriage. See A.G. Salzberger, Ouster of Iowa Judges Sends Signal to Bench, N.Y. TimES, June 27, 2010, at A12. We might speculate on the spillover effect of this election on other developments of state constitutional guarantees in sensitive and politicized areas. And would not the state judges be in greater jeopardy if they generated or raised the state issue rather than simply ruling on one raised by the parties? It is also interesting to note that there are impeachment discussions in the state legislature as to the other four Iowa justices who were not up for retention. Editorial, Impeachment as Intimidation, N.Y. Times, Jan. 12, 2011, at A22.

78. Davis, 79 P.3d at 78.

79. State v. Berger, 134 P.3d 378, 379 (Ariz. 2006).

80. Ewing v. California, 538 U.S. 11, 14 (2003); see supra note 64 and accompanying text.

81. Ewing, 538 U.S. at 14

82. Id.

83. See Berger, 134 P.3d at 384. 
photograph not to be cruel and unusual under federal law. ${ }^{84}$ The stacking of sentences of ten years - the mandatory minimum sentence for each count-posed no problem for the court, once again under federal law. ${ }^{85}$ The state law claim had not been argued at the supreme court level and the waiver was not excused. ${ }^{86}$

Let us assume that the Arizona court correctly divined the federal law. Why should that end the matter? Under the Arizona Declaration of Rights, is this approach reasonable? Did the people of Arizona desire to extend to prosecutors unlimited discretion to charge these types of related crimes as separate offenses with the imposition of mandatory consecutive minimum sentences? Why did the court not demand that counsel address these issues? ${ }^{87}$ Were the justices concerned about departing from the traditional passive role of the judiciary ${ }^{88}$ or the adverse reaction of the legislature or the people ${ }^{89}$

In other situations, parties cannot bind the judiciary by failing to raise constitutional objections. Advancement of party autonomy and the desire to undertake a passive role in the litigation process give way to more pressing concerns. For example, regarding the ban on cruel and unusual punishment, parties may not affirmatively consent to torture, the chain gang, physical castration, or death by strangulation. ${ }^{90}$ People demand more of the criminal justice system, and by failing to recognize this fact courts do a disservice to, and make a mockery of, constitutional

84. Id.

85. Id. at 383-84.

86. See supra note 60 and accompanying text.

87. Shouldn't the court report counsel's malpractice to the state bar under state counterpart to Rule 2.15(B) of the Model Code of Judicial Conduct? It provides as follows:

A judge having knowledge that a lawyer has committed a violation of the Rules of

Professional Conduct that raises a substantial question regarding the lawyer's honesty,

trustworthiness or fitness as a lawyer in other respects shall inform the appropriate authority.

Model Code OF JUdicial CONDUCT R. 2.15(B) (2007).

What wonders such reporting would accomplish in future cases. And if the judge does not believe he has the necessary knowledge of the dereliction, but only information indicating a substantial likelihood that the lawyer has committed a violation of the Rules of Professional Conduct (i.e., incompetence) he shall take appropriate action. See id. R. 2.15(D).

88. See supra note 16 and accompanying text.

89. See supra note 77 (discussing the ouster of Iowa judges).

90. See Jeffrey L. Kirchmeier, Let's Make a Deal: Waiving the Eight Amendment by Selecting a Cruel and Unusual Punishment, 32 ConN. L. REv. 615, 642-51 (2000) (examining the possibility of waiver of Eighth Amendment rights and arguing that such rights cannot be waived). A number of states permit castration by chemicals. See, e.g., CAL. Penal CodE $\S 645$ (West 2010); Fla. Stat. ANN. § 794.0235 (West 2007); TEX. GoV’T CODE ANN. § 501.061 (West Supp. 2010). 
guarantees-guarantees that not only protect individual human rights and dignity, but also impose limitations on the reach of legislative, executive, and judicial power.

Another point must be made. In cruel and unusual punishment jurisprudence, the Supreme Court fashions a national standard. ${ }^{91}$ But why should any state be bound to a national standard if local standards, mores, and customs reveal a different attitude toward implementation of these punishments? States should examine the imposition of punishment under their own version of cruel and unusual punishment, whether in the exact language of the federal provision or not. ${ }^{92}$ For example, sixteen states have abolished the death penalty. ${ }^{93}$ Illinois most recently joined the ranks in 2011. ${ }^{94}$ How many more states need to abolish the penalty before other states at least consider whether the punishment has been rendered cruel and unusual? Why should anything turn on whether counsel was astute enough to raise the state claim? Even if at one time the federal and state standards regarding what is cruel and unusual were exactly the same, time may reveal a fork in the river-a divergence in opinion that develops over time.

Rejection of a lockstep approach might also serve the salutary function of fostering a dialogue between the different judicial systems, perhaps leading to a change in the federal law if enough states extend the constitutional protection. Frankly, I am not at all sanguine that this will happen. After all, the Court seldom listens to voices other than its own. But one can always hope.

The failure to raise - or, once having been raised, to preserve-the cruel and unusual state constitutional provision should not be considered a waiver or, if a waiver, should be liberally excused. ${ }^{95}$ There is no sound reason to insist upon a formalistic designation of the state provision. There is no unfairness or surprise to anyone as long as the question is a matter of legal resolution and the parties have a right to brief the substantive question. Everyone should have been placed on constructive

91. The Court's disproportionality test clearly demonstrates this approach.

92. The lockstep approach seems singularly inapposite in the context where local standards should control.

93. Dave McKinney \& Stephen Di Benedetto, Quinn Signs Bill Repealing Illinois Death Penalty, CHI. SUN TIMES (Mar. 14, 2011), available at http://www.suntimes.com/4225981418/quinn-signs-bill-repealing-illinois-death-penalty.html.

94. Id.

95. Indeed this may be the occasion for a requirement of showing a knowing and voluntary waiver, although I doubt any state court will go this far in considering the state cruel and unusual punishment clause. 
notice, at the very least, that the state provision may control the disposition of the action. In another sense, however, there is an argument that raising the issue would be futile should the state high court adopt the lockstep approach, deciding the case the same way as the Supreme Court would in the federal arena. Just why courts would automatically default to the lockstep approach is questionable. A restrictive approach adopted by the Supreme Court in a badly reasoned and fractured opinion should not be applied at the state level to interpret state provisions without at least approval by the state courts. ${ }^{96}$ It matters not that we adopted the identical language of the federal provision. We certainly did not adopt every future Supreme Court decision no matter how aberrational or absurd its reasoning. There are many examples of state courts rejecting Supreme Court analyses of provisions that the state had copied verbatim. ${ }^{97}$

Let's take another example, this time one in which the constitutional provisions differ in language and in scope. In State v. Gant, the Supreme Court of Arizona had occasion to consider the legality of a search of a

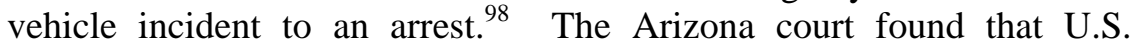
Supreme Court precedent did not address whether police could search the

96. We have already examined throughout this Essay the lockstep as well as the primacy approaches to interpretation of parallel constitutional provisions. Ruth McGregor posits another that she calls the "interstitial" approach, which promotes the goal of uniformity by conforming interpretation of the state provision "unless unique factors in the history or language of the state constitution justify diverging from the Supreme Court's interpretation of the comparable federal provision.” McGregor, supra note 22, at 276 (footnotes omitted). She cautions that this approach assumes the legitimacy of the federal approach. Id. She demands that the state court diverge from the federal approach only if it can articulate a specific reason based upon its unique law for doing so. Id. McGregor does not explain why she places the burden on the proponent of the state constitutional provision. It may be her deep concern that the state court avoid criticism that its approach is result-oriented. Is it not enough to show that the reasoning of the Supreme Court is baseless? Is it not enough to show that it has cast aside generations of precedent? Why do the state courts need to follow any aberrant or poorly reasoned decisions and adopt them into the fabric of state law? Perhaps it is her fear that in many situations state officers will have to know and follow two commands, rather than just the federal one. But that is not too much to ask of those who, after all, subscribe fealty to both constitutions.

97. For example, several states have rejected the tortured reasoning of Bell Atlantic Corp. v. Twombly, 550 U.S. 544 (2007), and Ashcroft v. Iqbal, 129 S. Ct. 1937 (2009), even though the same provision of the federal notice pleading requirement of Rule 8 had been adopted by the state. These state courts do not believe that the plausibility requirements of Twombly and Iqbal should be superimposed on the notice pleading requirement of the rule. See, e.g., Cullen v. Auto-Owners Ins. Co., 189 P.3d 344, 347 (Ariz. 2008); Colby v. Umbrella, Inc., 955 A.2d 1082, 1086 n.1 (Vt. 2008). I do not suggest that the people of a state could not require a lockstep interpretative approach, but instead that such a result need be shown by more than a mere copying of the language of the federal counterpart adopted at another time and under different circumstances.

98. 162 P.3d 640 (Ariz. 2007). 
vehicle after an arrest had been made and there was no showing of any need to protect the officers or preserve the evidence. ${ }^{99}$ The Arizona opinion, after noting that Gant did not claim a violation of the Arizona Constitution, observed that it would only consider whether the search violated the Fourth Amendment, ${ }^{100}$ even though there were precedents that afforded greater privacy protections under the Arizona Constitution. $^{101}$ The state high court held the search and seizure unconstitutional under federal law and the U.S. Supreme Court affirmed. Had the Arizona Supreme Court decided the federal constitutional claim against Gant, would it then have considered the state issue? If the U.S. Supreme Court had reversed Gant, should the state high court on remand have addressed the question under state law, even if it had not been raised previously by the defendant? ${ }^{102}$ If the answer to this question is affirmative, then why not excuse the waiver initially and decide the case on state grounds? Supreme Court cases could certainly be analyzed for whatever assistance they may provide. And under Michigan v. Long, a

99. Id. at 644 .

100. Id. at 642 n.1.

101. See State v. Ault, 724 P.2d 545, 556 (Ariz. 1985) (holding that seizure of shoes in defendant's house after entrance without permission and without warrant violates article 2, section 8 of the Arizona Constitution); State v. Bolt, 689 P.2d 519, 524 (Ariz. 1984) (holding that police practice of securing premises and rounding up occupants while awaiting the arrival of a search warrant violates article 2, section 8 of the Arizona Constitution); Pool v. Superior Court, 677 P.2d 261, 271-72 (Ariz. 1984) (holding that retrial of defendant after prosecutorial misconduct resulted in mistrial violates Arizona's double jeopardy clause despite trial court's finding that prosecutor did not have the intent to provoke the mistrial and directly contravening Oregon v. Kennedy, 456 U.S. 667 (1982)). For a more general discussion, see JAMES A. GARDNER \& JIM ROSSI, NEW FRONTIERS OF State Constitutional LAW: Dual Enforcement of Norms (2010); TOWARD A Usable Past: Liberty Under State Constitutions 3 (Paul Finkelman \& Stephen E. Gottlieb eds., 1991), William M. Wiecek, State Protection of Personal Liberty: Remembering the Future, in TOWARD A UsABLE PAST, supra, at 371. In Florida v. Casal, Chief Justice Burger in a concurrence noted his apprehension that state courts would "interpret state law to require more than the Federal Constitution," thereby undermining "rational law enforcement.” 462 U.S. 637, 639 (Burger, J., concurring). For other authorities, see other articles in this issue of Kansas Law Review. See generally Stephen R. McAllister, Individual Rights Under a System of Dual Sovereignty: The Right to Keep and Bear Arms, 59 U. KAN. L. REV. 865 (2011); Jeffrey M. Shaman, State Constitutional Law: The Right of Privacy and Same-Sex Marriage, 59 U. KAN. L. REV. 747 (2011); Jeffrey S. Sutton, What Does—and Does Not-Ail State Constitutional Law, 59 U. KAN. L. REV. 687 (2011).

Suppose counsel raises the state issue but fails to cite a case that is dispositive of the claim. In that situation, could any court rationally fail to excuse the oversight?

102. I do not contend that the Arizona courts had an obligation to raise the state privacy issues. They do not pertain to fundamental justice concerns and may present countervailing efficiency concerns such as the possible need for a remand to make additional factual findings. See infra note 125. 
decision in favor of Gant on clearly articulated state grounds would likely have precluded review of the federal question. ${ }^{103}$

To recapitulate, if counsel fails to raise a state constitutional issue in the lower courts in a manner that would be considered an obligatory duty on the court to review, what happens? Hornbook law exclaims, waiver! ${ }^{104}$ Courts need not consider the issue. Note that no rule states or even suggests that courts are powerless to consider it-just that they need not exercise their discretion to excuse the waiver. ${ }^{105}$ Courts may take several paths under these circumstances. First, insist upon a rule that leaves no room for relief. Justice Antonin Scalia believes that courts should not resolve an issue not adequately briefed or argued. ${ }^{106}$ Indeed, according to Justice Scalia and others, this is the premise of the adversarial system. ${ }^{107}$ But does it really make sense to adopt an unalterable rule that precludes consideration of such issues, even if the high court desires to consider them? ${ }^{108}$ And if one were to take the

103. 463 U.S. 1032, 1040-41 (1983).

104. See supra note 2.

105. There are several concerns regarding the standard for the exercise of discretion in these matters. Why exercise it in one case and not in another? Another concern relates to whether the judge is able to articulate the basis for the decision to exercise or not to exercise discretion. However difficult that may be, is that not the essence of discretion? After all, I am discussing discretionary, not ministerial, acts. Further, due process and equal protection concerns may arise if individuals are treated markedly differently. Like cases should be treated alike.

As stated elsewhere, certain federal trial protections cannot be waived unless the waiver is made knowingly and voluntarily. See supra notes 4-6 and accompanying text. I am currently not concerned with these categories of waivers. And, as previously noted, a state court has no enforceable obligation under federal law, aside from due process and equal protection concerns, to adopt the knowing and voluntary waiver doctrine regarding state constitutional guarantees. See supra note 2.

106. Justice Scalia notes that "[ $[\mathrm{t}] \mathrm{he}$ rule that points not argued will not be considered is more than just a prudential rule of convenience; its observance, at least in the vast majority of cases, distinguishes our adversary system of justice from the inquisitorial one.” United States v. Burke, 504 U.S. 229, 246 (1992) (Scalia, J., concurring), superseded by statute as stated in Eshelman v. Agere Systems, Inc., 554 F.3d 426, 441 (3d Cir. 2009). I wonder whether this rule will soon be enshrined in the Due Process Clause. I suppose we would have to discuss foreign law in order to render a fair comparison-a practice that is frowned upon by several justices. For an excellent discussion of these problems at the federal level, see Frost, supra note 9.

107. See Gonzales v. Carhart, 550 U.S. 124, 169 (2007) (Thomas, J., concurring) ("I also note that whether the...Act... constitutes a permissible exercise of Congress' power under the Commerce Clause is not before the Court. The parties did not raise or brief that issue; it is outside the question presented; and the lower courts did not address it.”); Whitman v. Am. Trucking Ass'ns, 531 U.S. 457, 486-87 (2001) (Thomas, J., concurring) (refusing to address a potential constitutional issue regarding a federal statute that parties did not raise).

108. As noted by one scholar:

In State v. Jewett, the Supreme Court of Vermont lamented the parties' failure to present

"any substantive analysis or argument" on the state constitutional claim, that the police 
position that the high court's desires may excuse a party's waiver, what are the boundaries of that trump card? Richard Posner, on the other hand, takes the position that the judge is more than just an umpire "calling balls and strikes" between the parties. ${ }^{109}$ Are there considerations beyond insistence on party autonomy and presentation that might call for a judge not to decide matters that have not been originally presented? And if deviation from the strict adherence to the principle of waiver is allowed, when should it be exercised? These questions touch the sensitive area of the role of courts in adjudication. Do we adhere to the antiquated doctrine that courts exist solely to resolve controversies between parties and that law development is merely a byproduct? If we still subscribe to that model, perhaps waiver should seldom be excused, at least in civil cases. But can we insist upon a strict waiver rule in criminal cases generally? In Berger? ${ }^{110}$ The role of the courts certainly includes the development of a coherent body of lawone that can be understood and applied by the people and by the other branches of government. In other words, development of law is an integral part of the judicial process. Does not strict application of the waiver doctrine impede that function?

Despite the exhortations against issue creation, ${ }^{111}$ or considering unraised issues without specifying the reasons, courts have been unwilling to implement the draconian effect of a waiver in all

had illegally stopped and arrested the defendant. The court directed the parties to file supplemental briefs addressing the matter, and proceeded to offer practitioners a primer in the various modes of constitutional argument, from historical and textual arguments to arguments based upon precedent and policy considerations. The court emphasized the importance of developing arguments about the meaning and application of constitutional [law $]. . .$.

The Vermont court assumed that developing well grounded constitutional arguments is not beyond the competence of most attorneys.

Friedman, supra note 45, at 311-12 (footnotes omitted). The Vermont counsel did raise the state constitutional objection. State v. Jewett, 500 A.2d 233, 234 (Vt. 1985). The concern of the Vermont court was the failure to develop the arguments. Id.

In another case, a Ninth Circuit majority opinion noted its approval of the practice of requesting supplemental briefs by the parties and amicus on an issue that in its view was a necessary antecedent to the one presented by the parties. Warren v. Comm'r of Internal Revenue, 282 F.3d 1119, 1120 (9th Cir. 2002). The dissent characterized the procedure as "injudicious.” Id. at 1123 (Tallman, J., dissenting).

The court always has the power to appoint amici to aid in the presentation of the unraised or poorly presented state issue. See, e.g., Alabama v. Shelton, 534 U.S. 987, 987 (2001) (inviting a particular person to file an amicus brief).

109. See Smith v. Farley, 59 F.3d 659, 665 (7th Cir. 1995).

110. See supra notes $47-60$ and accompanying text.

111. See supra note 9 and accompanying text. 
circumstances. The Supreme Court put it best when it noted that a court of appeals has discretion to correct plain errors or defects affecting substantial rights that were forfeited because they were not timely raised in the district court if the errors "seriously affect the fairness, integrity or public reputation of judicial proceedings." "112

Whatever one's position on these matters might be if we were writing on a clean slate, the fact of the matter is that we decidedly are not. The question does not come down to whether, ${ }^{113}$ but to when, ${ }^{114}$ and with what degree of liberality and transparency the court may excuse a

112. United States v. Olano, 507 U.S. 725, 736 (1993) (citing United States v. Atkinson, 297 U.S. 157, 160 (1936)); see also Singelton v. Wulff, 428 U.S. 106, 120-21 (1976) (noting general rule against considering issues not raised in lower court but permitting discretion to do so where resolution is beyond doubt or an injustice might otherwise occur). There are many other cases to the same effect. See, e.g., Luo v. Mikel, 625 F.3d 772, 778 (2d Cir. 2010) (noting that ordinarily court will not consider an issue raised for the first time on appeal, but permitting deviation in two instances: "where consideration of the issue is necessary to avoid manifest injustice" or "where the issue is purely legal and there is no need for additional fact finding"); United States v. PortilloMendoza, 273 F.3d 1224, 1227 (9th Cir. 2001) (noting that waiver is excused in "exceptional circumstances, especially in criminal cases”); see also Young v. United States, 315 U.S. 257, 259 (1942) (holding that administration of criminal justice system is too significant to be left to the stipulation of parties). This Essay goes a step further with respect to the adjudication of state constitutional issues in state courts - granting the courts discretion to liberally excuse the waiver of state constitutional rights in serious criminal proceedings.

113. An insistence upon adherence to the adversary system, party presentation, and party autonomy may work in many cases. But where it interferes with justice, the rendering of a correct decision, or fairness to the parties and society, it should be tempered with the judicial discretion to override- especially when a defendant's liberty is at stake. The Supreme Court said it best nearly three generations ago:

Rules of practice and procedure are devised to promote the ends of justice, not to defeat them. A rigid and undeviating judicially declared practice under which courts of review would invariably and under all circumstances decline to consider all questions which had not previously been specifically urged would be out of harmony with this policy. Orderly rules of procedure do not require sacrifice of the rules of fundamental justice.

Hormel v. Helvering, 312 U.S. 552, 557 (1941). Hormel was a civil case. I believe the normative values set forth therein would apply with even greater force in criminal proceedings. And in death penalty cases, courts independently review the record searching for fundamental error. See, e.g., State v. Stokley, 898 P.2d 454, 465 (Ariz. 1995).

114. It is clearly easier to excuse a waiver at the trial court level than at the appellate one. Even if the trial court improperly excuses the waiver, many jurisdictions will not permit an appeal of such an interlocutory order at the time of its rendition. And if the defendant is later acquitted, double jeopardy attaches and the order is unreviewable. If he is convicted, he cannot seek review of the trial court's order as it operated in his favor. It is also highly unlikely that prosecutors can successfully insist upon reinstatement of the waiver should the case be remanded for a new trial. 


\author{
waiver. ${ }^{115}$ This Essay develops judge-made principles regarding these \\ questions. $^{116}$
}

115. Transparency is a concern because of the apprehension that courts may decide cases on grounds not presented by the parties without any input from any external source. This is not the way to render rulings that may significantly affect the development of the law. For example, in Bell Atlantic Corp. v. Twombly, 550 U.S. 544, 576 (2007), the Court examined the fifty-year-old pleading case of Conley v. Gibson, 355 U.S. 41 (1957). Conley articulated "the accepted rule that a complaint should not be dismissed for failure to state a claim unless it appears beyond doubt that the plaintiff can prove no set of facts in support of his claim which would entitle him to relief.” Twombly, 550 U.S. at 577 (citing Conley, 355 U.S. at 45-46). Without argument on the issue of the meaning of this accepted fifty-year-old "rule," the Court interred it, noting that it "had earned its retirement.” Id. at 563. The Court's recasting of the meaning of the statement is rather unconvincing. But even more significant for purposes of this Essay and the idea of transparency is a passage from Justice Stevens's dissent:

Petitioners have not requested that the Conley formulation be retired, nor have any of the six amici who filed briefs in support of petitioners. I would not rewrite the Nation's civil procedure textbooks and call into doubt the pleading rules of most of its

States without far more informed deliberation as to the costs of doing so.

Id. at 579 (Stevens, J., dissenting).

116. For further development in the area of federal practice, see Cravens, supra note 9; Frost, supra note 9.

Perhaps the best-known example in which a court decided a case on a ground not raised or presented by the parties is Erie R.R. Co. v. Tompkins, 304 U.S. 64 (1938). After hearing the opening arguments of counsel, Chief Justice Hughes declared: "If we wish to overrule Swift v. Tyson, here is our opportunity.” Irving Younger, What Happened in Erie, 56 TEX. L. REV. 1011, 1028 (1978). Judges, scholars, and law students alike have pondered for nearly seventy-five years why the decision was expressly based on constitutional rather than statutory grounds. Perhaps presentation by the parties or amici might have assisted the Court in this regard.

The Court has never foreclosed independent examination of its own jurisdiction, whether after a default or otherwise. Marbury v. Madison sired the host of these cases. 5 U.S. (1 Cranch) 137 (1803). In Marbury, James Madison did not appear to argue the case. Dean Alfange, Jr., Marbury v. Madison and Original Understandings of Judicial Review: In Defense of Traditional Wisdom, 1993 SuP. CT. REv. 329, 365. Chief Justice Marshall eventually decided the case on the unconstitutionality of the statute, giving the Court original jurisdiction. Marbury, 5 U.S. at 174-76. If that were all, we would pay scant attention to the decision for purposes of this article. But there is more-lots more. Chief Justice Marshall canvassed the breadth of the law for arguments that Madison might have made had he appeared. The Chief Justice exclaimed:

After searching anxiously for the principles on which a contrary opinion may be supported, none have been found which appear of sufficient force to maintain the opposite doctrine.

Such as the imagination of the court could suggest, have been very deliberately examined, and after allowing them all the weight which it appears possible to give them, they do not shake the opinion which has been formed.

Id. at 159. It is noteworthy that these arguments rested on ordinary principles of property law as well as more grave issues of the powers of the president. Marshall undertook to decide all of them without distinction. Noting the approach adopted by Marshall, one scholar had this to say:

Only after he completed this exercise did Justice Marshall determine that the Court had no jurisdiction over the case. The simpler approach would have been to dispense with the case on the jurisdictional point without going to the trouble of imagining an absent party's legal arguments. However, the Court considered it a matter of sufficient importance to conduct a full exploration of the case in order to reach the best- that is, the 
This Essay has explored the question of high court consideration of state constitutional issues in criminal matters not initially raised or insufficiently presented by the parties at the trial court level. It assumes

most correct-possible result. This is perhaps an extreme example, but it illustrates the breadth of possibilities for how a judge may consider a matter and how he may define his role.

Cravens, supra note 9, at 252. This approach is extreme, and perhaps activist in the modern sense of the term but certainly was the foundational building block of the role of the courts.

In Washington v. Davis, the Court held that the Equal Protection Clause prohibits intentional discrimination despite the parties' concession that the proper test barred disparate treatment. 426 U.S. 229, 239-41, 249 (1976). Party autonomy gave way to a higher principle: proper development of the law.

Other areas are too important to leave unattended despite the failure of the parties to raise or properly present sound legal arguments. First-year law students are familiar with the consequences of failure to raise subject matter jurisdiction defects on direct review in the federal system. The well-known case of Louisville \& Nashville R.R. v. Mottley is typical. 211 U.S. 149 (1908). After being injured by the defendant railroad, the Mottleys settled a lawsuit for free transportation on that railroad during their lives. Id. at 150 . The defendant lived up to the terms of the contract for thirtyfive years. Id. Thereafter they declined to renew the passes claiming that a federal statute forbade the giving of free passes. Id. The Mottleys initiated suit in federal court claiming that the statute did not embrace passes to them given in consideration of the release of their negligence claims. Id. at 151. Moreover, they argued that should the statute cover the case it deprived plaintiffs of property without due process of law. Id. at 151-52. Plaintiffs won in the lower court. Id. In the Supreme Court the parties raised only the two questions of federal law presented to the lower court: interpretation of the federal statute and the Fifth Amendment issue. Id. However, the Court refused to reach these issues:

We do not deem it necessary, however, to consider either of these questions, because, in

our opinion the court below was without jurisdiction of the cause. Neither party has questioned that jurisdiction, but it is the duty of this court to see to it that the jurisdiction of the circuit court, which is defined and limited by statute, is not exceeded. Id. at 152 .

After stating that there was no diversity jurisdiction, it determined that the "arising under" statute, the other basis of jurisdiction considered, was unavailing. Id. The Court therefore reversed and remanded to the circuit court with instruction to dismiss the suit for want of subject matter jurisdiction. Id. at 154 .

Several points pertinent to this Essay should be made. The Court noted that neither party questioned the jurisdiction of the lower court. Id. at 152. Yet it felt compelled to do so on its own. Id. Nor is there any indication that the Court requested either party to submit any arguments on the issue of subject matter jurisdiction.

With regard to deciding the issue sua sponte without an opportunity for party presentation, one could argue in Mottley that the "well-pleaded complaint" principle had already been established and there was no point in seeking elaboration from counsel. But such assurances by the Justices do not satisfy the constitutional right to be heard once the Court decides that the issue becomes critical to the disposition of the case.

There are other areas in which the Supreme Court has intervened to raise and decide an issue despite lack of party presentation. Questions of standing and justiciability that touch upon the role of the courts and constitutional and prudential limitations on its decisionmaking authority certainly account for an important swath. Then, too, courts may sua sponte abstain from deciding a case or an issue therein because of federalism or other systemic and structural concerns. Cf. Cravens, supra note 9, at 264-66. 
that the appellate court has no authority to decide factual issues in the first instance. However, it would appear not beyond the power of the appellate court to remand for additional findings of fact. ${ }^{117}$ Several significant questions would still remain under the assumption that the proposed liberality "rule" that considering unraised issues of state constitutional law in criminal cases should become the accepted practice.

First and foremost, should the practice be incorporated in a court rule that would encapsulate the criteria that should be adopted by the court in the particular case? ${ }^{118}$ Or should the formulation of the criteria be left to the creative judicial processes without benefit of a particular rule? ${ }^{119}$ Either process is preferable to nontransparent forgiveness without any opportunity for party presentation. ${ }^{120}$

Second, how does the state high court recognize an issue that has not been initially raised or properly presented? The dereliction may surface in many ways. A judge in a lower court may note it; ${ }^{121}$ or counsel may

117. There is authority that district courts should not address facts not raised by the parties. See United States v. Cofield, 272 F.3d 1303, 1307 n.4 (11th Cir. 2001) ("The district court erred in judicially-noticing the report, and judicially-noticing facts about an issue not raised by the parties or supported by the evidence, and assigning weight to those facts in its credibility determinations.”). This has nothing to do with the propriety of a remand for such determinations after giving the parties an opportunity to develop the facts.

118. Several rules governing lower court discretion may be noted. See FED. R. CIV. P. 52(a) (governing findings and conclusions at trial); FED. R. CRIM. P. 23(c) (governing nonjury trials); FED. R. CRIM. P. 32 (governing sentencing). Rule 14(1)(a) of the Rules of the Supreme Court of the United States provides in pertinent part: "Only the questions set out in the petition [for certiorari], or fairly included therein, will be considered by the Court.” SUP. Cт. R. 14(1)(a). This Rule has not always prevented the Court from deciding issues not presented by the advocates. See supra note 116.

119. I am agnostic regarding which approach to adopt. The rulemaking process may be cumbersome in some jurisdictions and it may be more efficient to first develop these principles as a common law exercise. Thereafter, a rule may be proposed based upon the experience of the court decisions.

120. An example of the need for transparency that arises from my own practice comes to mind. Many years ago, I was retained as plaintiff's counsel in an antitrust case against the NCAA in federal court. The question arose whether the court had personal jurisdiction and venue. The defendant moved to dismiss the case on these two grounds and the court held an evidentiary hearing on the issues. The arguments were solely addressed to personal jurisdiction and venue. In a few weeks the judge called a meeting of counsel to announce his decision. He came right to the point. He found that there was jurisdiction as well as venue. Then he lowered the boom: The case would be transferred to a more convenient location across the continent. Now, even assuming the issue had been raised by the NCAA, it remains perfectly clear to me that argument on that issue was completely submerged. There was no realistic opportunity to offer arguments against the transfer on the basis of inconvenience or expense.

121. This Essay has not approached the issue of waiver from the perspective of lower courts. While they may have more discretion in issue creation as a practical matter, they ordinarily have neither the time, resources, nor inclination to devote to issues not raised by the parties. 
come to understand her delinquency and request that the high court consider it. Then again, lawyers in the clerk's office or staff attorney's office may note the issue; or the justices themselves - or their judicial clerks - either upon reading the petitions for review, the briefs on appeal, or hearing oral argument, may become aware of the unraised issue. ${ }^{12}$

Third, what should the justices do if they perceive an unraised issue? If the resolution of the issue might clearly benefit a criminal defendant and it is an issue of constitutional dimension, the court should give the parties an opportunity to address the issue. On the other hand, a real problem arises if the justices are in equipoise-that is, they are unsure how they would rule on the issue if presented. At this juncture, where neither party raised the issue initially, the high court should liberally excuse the waiver ${ }^{123}$ and allow both parties to submit written briefs and perhaps argue the question of law. ${ }^{124}$ It may also appoint amici to present oral or written arguments to the court. Whether the case should first be remanded to lower courts for additional proceedings depends on the nature of the defense. If additional facts are necessary for a proper resolution of the issue, then by all means the case should be returned to the lower court. ${ }^{125}$ If only legal issues are involved, the high court may certainly decide without reference to the lower court's opinion on the issue. $^{126}$

What should the court do if after importuning defense counsel to brief a matter, counsel insists that it would be fruitless? There are several courses open to the court. First, it can abandon its concern. Abandoning a potentially viable state constitutional claim is a troublesome alternative when life and liberty are at stake and the constitutional issue calls into question limitations on the power of state legislative and executive departments. Second, the court may appoint

122. Of course it is always possible that the justices will also miss the point.

123. For example, it may not be known whether the error, even if otherwise clear, may in fact be harmless and thus not dispositive of the case. This is just another reason the court should receive input from both parties.

124. See, e.g., State v. Davis, 79 P.3d 64, 67 (Ariz. 2003) (noting that the court had asked the parties to brief whether the Arizona Constitution provides greater protection against cruel and unusual punishment than does the Eighth Amendment); see also supra notes 76-78 and accompanying text.

125. Perhaps the need to remand for additional factfinding militates against issue creation by the high court. At the very least, it is a factor that should be considered.

126. It has been pointed out to me that in the absence of remand the lower court may feel left out of the process. Even were that true, which in view of the large and increasing caseload of lower courts seems debatable, efficiency concerns may militate against further lower court proceedings. 
amicus to argue the issue. ${ }^{127}$ As noted previously, amici are readily available to present arguments in the Supreme Court. ${ }^{128}$ They may not, however, be so readily available in state court proceedings, especially when the case or issue is not a prologue to further proceedings in the Supreme Court. ${ }^{129}$ Perhaps the law schools can do a service in this regard. Why should the schools not provide a law school clinic or think tank which would review cases for state law constitutional issues and, when requested by the court or as otherwise specified in a rule, provide written briefs and perhaps oral argument on selected questions of state constitutional law? ${ }^{130}$

Fourth, what is the effect of courts' widespread adoption of the principle of liberally excusing waivers in state courts? We know that appellate courts review lower court proceedings to determine whether trial counsel's assistance fell below the level deemed to be "effective assistance of counsel” for Sixth Amendment purposes. ${ }^{131}$ We also know that it is difficult to upset a conviction on Sixth Amendment grounds. ${ }^{132}$ Will the failure to raise state constitutional issues be even less likely to be overturned on Strickland grounds or state equivalents if state courts liberally excuse waivers - that is, if they liberally entertain arguments

127. Alabama v. Shelton, 534 U.S. 987, 987 (2001) (requesting Charles Fried file an amicus brief and argue for ten minutes, taken from petitioner's time for oral argument, in opposition to a Ninth Circuit opinion).

128. See supra note 108.

129. In view of Michigan $v$. Long, it is unlikely that any decision of the highest state court clearly based on state grounds will ever be reviewed by the U.S. Supreme Court. 463 U.S. 1032, 1041 (1983) ("If the state court decision indicates clearly and expressly that it is alternatively based on bona fide separate, adequate, and independent grounds, we ... will not undertake to review the decision.”).

130. Suppose the high court sua sponte decides the state constitutional law issue against the defendant. What should it do? Let us take Berger's case as an example. See supra notes 47-60 and accompanying text. Assume the state court decides without input from counsel, amici, or any law school clinic that there really is no difference between the state and federal provisions. Should it write an opinion setting forth its conclusions? Would that opinion be entitled to the equivalent stare decisis effect in lower courts and in the state high court as opinions that are rendered after a full briefing and argument? And if not equivalent, what are the precedential consequences of those cases? Does any of this really matter? Is not the bottom line that Berger is committed to prison for two hundred years, and for all we know, the highest court in Arizona never considered the state constitutional ground. Need anything else be said?

131. Federal courts of appeal and nearly all state courts hold the proper standard for attorney performance is "reasonably effective assistance." Strickland v. Washington, 466 U.S. 668, 683 (1984) (citing Trapnell v. United States, 725 F.2d 149, 151-52 (2d Cir. 1983)).

132. See id. at 694 ("The defendant must show that there is a reasonable probability that, but for counsel's unprofessional errors, the result of the proceeding would have been different.”). 
that previously would have been thought to have been waived? This remains to be examined in another essay.

Fifth, should the state high court adopt a discretionary rule or principle excusing waiver, will the failure to excuse in a particular case render the judgment subject to scrutiny under federal and state due process grounds? While I doubt that this consequence will occur, one should note that the exercise of discretion must be based on more than mere whim.

Sixth, some may point to Justice Brandeis's admonition against deciding constitutional issues when unnecessary for the resolution of the case. $^{133}$ But Justice Brandeis was very careful to limit the scope of his concern. A court should not decide constitutional issues when there are other grounds for the decision. ${ }^{134}$ We do not face that predicament. No other grounds for the decision are availing to state criminal defendants like Berger. Indeed, with respect to the development of state constitutional law, there may be a need to base the decision on the local provision giving primary significance to local needs and concerns. Indeed, several scholars and jurists hold this opinion. ${ }^{135}$

One scholar has graphically illustrated the point made herein with the following observation:

We have heard from some of the most eminent figures of the American judiciary today: Chief Judge Judith S. Kaye of New York, Chief Justice Shirley S. Abrahamson of Wisconsin, Chief Justice Christine Durham of Utah, and Chief Justice Jim Hannah of Arkansas. To be perfectly frank, let me tell you that I for one-and I am certainly not alone in this view-would much prefer that my rights and liberties were placed in their hands than in the hands of the majority of the current United States Supreme Court. ${ }^{136}$

Seventh, there may be other reasons not to reach out and decide a case on an unraised state constitutional ground. In many states, there has been little opportunity to develop a coherent body of state constitutional

133. See Ashwander v. Tenn. Valley Auth., 297 U.S. 288, 345 (1936) (Brandeis, J., concurring).

134. See id. at 345-48 (listing rules under which the Supreme Court avoided constitutional questions). A noted casebook refers to the Brandeis opinion as the canonical citation for the avoidance doctrine. See Richard H. FALLON, JR. ET AL., HART AND WECHSLER's THE FEDERAL COURTS AND THE FEDERAL SYSTEM 76 (6th ed. 2009).

135. See generally Brennan, supra note 1, at 491 (stressing state courts cannot rest when affording citizens the protections of the Federal Constitution, as state constitutions have protections often extending beyond those required by federal law).

136. Bonventre, supra note 1, at 841. 
law, and to that extent the likelihood of error magnifies, especially where there is a dearth of party input. Fewer decisions on issues may easily translate into fewer mistakes and into greater efficiencies in the judicial processes. Of course, these and other concerns must always be weighed and balanced against the goals of fairness and justice in the particular case and the development of a coherent body of state law.

Enough pleas already. Since the 1970s, judges and scholars have implored counsel to raise state constitutional claims. But for some unfathomable reason, counsel, through oversight or design, flout that sound advice. There is so little to lose and so much to gain by consideration of the state constitutional ground as the primary source of rights and liberties of the people. If state courts focus on the state constitution, Supreme Court opinions could still be analyzed for whatever light they may shed. ${ }^{137}$ And analysis of the state constitution will provide useful guidance to state law enforcement and judicial officers. In view of these benefits, the high courts should liberally excuse waivers of unraised state constitutional grounds, at least in serious criminal cases. Nevertheless, I concede that if the right is protected by federal law there may be no need to address that state law question at all. In addition, if the state law issue is resolved against the defendant, the court still has the opportunity to decide the federal issue. $^{138}$

In the final analysis, states should protect their citizens in the way the states think best. That protection can be assured only if the courts liberally relieve defendants from waivers of these valuable protectionsat least until a body of state law against the defendant's position has been developed. Though in certain cases the state courts have a federal obligation to consider the waiver of certain federal constitutional trial rights under the "knowing and voluntary" test, it is an open question whether such a duty should be imposed by the state high courts in the adjudication of state constitutional rights. The resolution of this question is best left to another day. Whether the liberality rule should also be applied in civil cases in the state courts, and if so under what circumstances, should also be examined more fully at another time.

137. Of course, should the state constitution afford no protection, the Federal Constitution may still have to be examined.

138. Another problem may emerge. If the defendant raises only the state issue and it is decided against her, should the court liberally excuse the waiver of the federal constitutional right? Is that a question to be resolved by federal law? We need not address that issue at the present time. The safest course for the defendant is to raise both state and federal claims at the outset. 
As previously noted, rejection of the strict waiver rule in favor of a more liberal issue creation approach in criminal cases admittedly carries potential costs. However, the benefits to the defendant caught up in the criminal adjudicative process and to society at large far outweigh the burdens. 